\title{
ENERGY FLUX DAMPING DUE TO CORAL REEFS USING MODULAR ORGANIC- SHAPED 3D PRINTED ELEMENTS
}

\author{
Edgar Mendoza, Engineering Institute, National Autonomous University of Mexico, emendozab@ii.unam.mx \\ Ana Rios, Engineering Institute, National Autonomous University of Mexico, ariosp@ii.unam.mx \\ Ismael Mariño-Tapia, CINVESTAV-Merida, Mexico, imarino@mda.cinvestav.mx \\ Rodolfo Silva, Engineering Institute, National Autonomous University of Mexico, rsilvac@ii.unam.mx
}

\section{INTRODUCTION}

The protective role of coral reefs on beaches has been widely demonstrated and studied (e.g. Ferrario, et al. 2014). The principal mechanism through which this is achieved is wave energy dissipation mainly due to wave breaking and bottom friction. Moreover, several beaches have been seen to start eroding or worsen their erosion patterns with the loss or damage to reef barriers. Recently, the effectiveness of coral reefs as wave attenuating barriers was found to have direct relation to a roughness index estimated as a function of the Nikuradse roughness (Rogers, et al., 2016; Mariño-Tapia et al, 2015).

Several projects have been implemented around the world which aim to mimic the services coral reefs bring to beaches (coastal protection, wave energy attenuation, habitat supply). These generally use artificial structures, composed of geometric elements with regular shape. The main goal of this work is to test scale model replicas of a natural coral reef and compare their performance as wave energy attenuator via the energy flux damping. The organic shape is expected to reduce the wave height efficiently and is likely to be colonized rapidly (although only hydrodynamic related variables will be reported).

\section{LABORATORY EXPERIMENTS}

The organic element used for the reproduction of the coral reef is based on the shape of the Acropora palmata species which is present along the Mexican Caribbean and in many other tropical seas worldwide.

The coral individuals were designed with a software to freely modify the shape and get a realistic pattern. To ensure stability of the elements and to facilitate the construction of the barrier, the individuals were placed over modular elements (Cardenas et al, 2016). Both, the small scale model and the full scale structure are 3D printed (see figure 1).

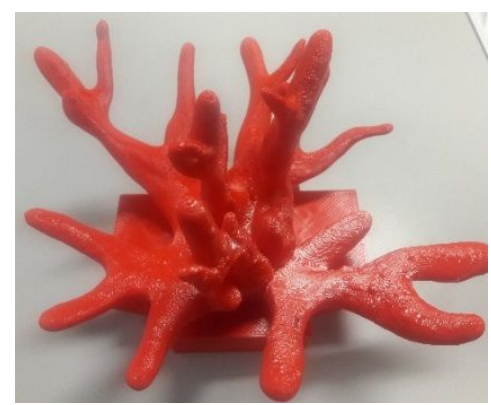

Figure 1 - Image of the 3D printed coral replica

Three different kinds of models were printed and they were ordered in the structure by their exposure to waves, i.e. smaller ones facing the waves, larger ones at the crown of the structure and the largest on the protected slope.

The barrier was placed over a sandy beach constructed within the wave flume at the National University of Mexico. Two positions of the barrier were tested, in the first the height of the barrier was half the still water depth and in the second the height of the structure was equal to the still water depth. The free water surface and velocity profiles in front of and behind the barrier were measured. The final beach and dune profiles were used to evaluate the morphological response.

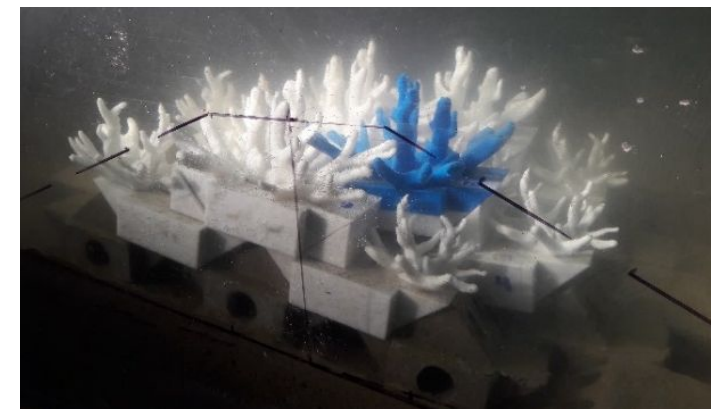

Figure 2 - Reproduction of a coral barrier in the wave flume; showing the modular elements

\section{INSITU MEASUREMENTS}

The comparison between the laboratory results and the data registered for the coral reef Limones, Mexican Caribbean will be shown in the full paper. In situ records show that the energy flux damping due to the presence of the coral reef can be used as an indicator of the protective role of the natural barrier.

\section{REFERENCES}

Cárdenas-Rojas, Mendoza, Verduzco-Zapata, Silva. (2016). Análisis hidráulico de un dique sumergido homogéneo optimizado para funcionar como arrecife artificial. XXVII Congreso Latinoamericano de Hidráulica Lima, Perú, 508- 516.

Ferrario, Beck, Storlazzi, Micheli, Shepard, Airoldi. (2014). The effectiveness of coral reefs for coastal hazard risk reduction and adaptation. Nature communications, 5 , 3794.

Mariño-Tapia, Huntley, Franklin. (2015). Disipación de energía de oleaje en regiones de alta rugosidad arrecifal: efectos en bajas y altas frecuencias. Poster. Reunión Anual de la Unión Geofísica Mexicana. Puerto Vallarta Noviembre 2015.

Rogers, J. S., S. G. Monismith,D. A. Koweek, and R. B. Dunbar. (2016). Wave dynamics of a Pacific Atoll with high frictional effects, J. Geophys. Res. Oceans, 121, 350367, doi:10.10022015JC011170 